Fecha de recepción: mayo 2021 Fecha de aceptación: junio 2021 Versión final: julio 2021

\section{Los internados del miedo: cuando la realidad supera la ficción}

Mónica Gruber ${ }^{(1)}$

Resumen: Los periodistas Montse Armengou y Ricard Belis realizaron el documental Los niños perdidos del franquismo (Els nens perduts del franquisme, 2002) para la cadena TV3 de Televisio de Catalunya, España. El material fílmico resumía solo una parte de lo que volcarían luego en un libro homónimo. Finalizada la pesquisa, las denuncias seguían llegando. Las víctimas querían que alguien las escuchase. Tal como señala Belis, no importaba que no existiesen documentos probatorios ya que las denuncias sobraban y había que atenderlas. De ese modo, los realizadores encaminaron sus pasos hacia un ignoto episodio del pasado español.

Los internados del miedo tranquilamente podría ser el título de una película de terror, pero no lo es, ya que la realidad, supera la ficción. Los internados del miedo (Els internats de la por, 2015) de Montse Armengou y Ricard Belis recoge el testimonio de las víctimas de vejaciones, privaciones y hasta de experimentos médicos en los internados para niños de la época franquista. Hospitales Psiquiátricos, Preventorios, Casa Cuna e Internados escribieron las páginas más deleznables de la historia española, en las que la tortura, la violación, el trabajo esclavo de menores y la venta de niños, formaron parte.

Nos proponemos abordar este material documental para ayudar a restituir la voz y la identidad de las víctimas silenciadas. ¿Puede haber sido la pobreza una de las causas de su situación? ¿Qué sucedió con los hijos de madres solteras? ¿Y aquellos cuyos padres eran reconocidamente antifranquistas? Estas y otras preguntas orientarán nuestra búsqueda. Trataremos de establecer cuáles pudieron ser algunas de las causas que colocaron a estos menores en una situación de mayor vulnerabilidad, convirtiéndolos en blanco fácil de dichas prácticas. No debemos perder de vista que, el Estado, la Iglesia y algunas empresas en flagrante connivencia fueron los ejecutores de un macabro y sistemático programa.

Palabras clave: Franquismo - representación audiovisual - niños - memoria

[Resúmenes en inglés y portugués en la página 234]

(1) Licenciada y Profesora en Artes (UBA). Docente UP en el Área Audiovisual de la Facultad de Diseño y Comunicación, UBA Facultad Diseño de Imagen y Sonido; Museo Social Argentino, de la Universidad Tecnológica Nacional y de los Profesorados Artísticos del Gobierno de la Ciudad. Directora del Proyecto PIA de Investigación Pervivencia y rese- 
mantización de los mitos en el mundo contemporáneo. De la narración oral a la pantalla global (FADU - UBA). Ha participado como ponente en Congresos Internacionales y Nacionales.

\section{Introducción}

Los periodistas Montse Armengou ${ }^{1}$ y Ricard Belis ${ }^{2}$ realizaron el documental Los niños perdidos del franquismo (Els nens perduts del franquisme, 2002) para la cadena TV3 de Televisio de Catalunya, España. El material fílmico resumía solo una parte de lo que volcarían luego en un libro homónimo. Finalizada la pesquisa, las denuncias seguían llegando. Las víctimas querían que alguien las escuchase. Tal como señala Belis, no importaba que no existiesen documentos probatorios ya que las denuncias sobraban y había que atenderlas. De ese modo, los realizadores encaminaron sus pasos hacia un ignoto episodio del pasado español. Los internados del miedo tranquilamente podría ser el título de una película de terror, pero no lo es, ya que la realidad supera la ficción. Los internados del miedo (Els internats de la por, 2015) de Montse Armengou y Ricard Belis recoge el testimonio de las víctimas de vejaciones, privaciones y hasta de experimentos médicos en los internados para niños de la época franquista. Hospitales Psiquiátricos, Preventorios, Casa Cuna e Internados escribieron las páginas más deleznables de la historia española, en las que la tortura, la violación, el trabajo esclavo de menores y la venta de niños, formaron parte.

Nos proponemos abordar este material documental para ayudar a restituir la voz y la identidad de las víctimas otrora silenciadas. ¿Puede haber sido la pobreza una de las causas de su situación? ¿Qué sucedió con los hijos de madres solteras? ¿Y aquellos cuyos padres eran reconocidamente antifranquistas? Estas y otras preguntas orientarán nuestra búsqueda. Trataremos de establecer cuáles pudieron ser algunas de las causas que colocaron a estos menores en una situación de mayor vulnerabilidad convirtiéndolos en blanco fácil de dichas prácticas. No debemos perder de vista que el Estado, la Iglesia y algunas empresas -en flagrante connivencia- fueron los ejecutores de un macabro y sistemático programa. Cabe señalar que, hasta la fecha, las víctimas no han recibido aún pedido de disculpas por parte de ningún gobierno democrático español, así como tampoco han sido reconocidos como víctimas del franquismo. Ante la vacancia de organismos gubernamentales destinados a la investigación de dichas atrocidades, muchos de los damnificados se han sumado a la denuncia sobre crímenes de lesa humanidad radicada en el juzgado de la Dra. María Romilda Servini, Jueza argentina. La llamada Querella Argentina recoge estas acusaciones. El proceso judicial avanza con lentitud, en un intento por abrir una brecha que permita restañar las heridas, aunque no se pueda olvidar. 


\section{Descenso a los infiernos}

La Guerra Civil sumió a España en un enfrentamiento fratricida que socavó los cimientos de la península exponiendo lo peor de ambos bandos. La grieta enfrentó a vecinos, familiares y hasta familias completas. El fin de la contienda, en 1939, lejos de restablecer la paz dejaba abiertas profundas heridas. El nacional-catolicismo impondría un férreo control sobre todas las actividades políticas, sociales y religiosas. Las leyes promulgadas durante la II' República fueron derogadas es así que, entre otras tantas disposiciones, los divorcios civiles quedaron sin efecto y las mujeres volvieron a la tutela de los esposos.

La labor masculina consistía en garantizar el control familiar, mientras que la iglesia, sitio de reunión diario obligatorio, se hacía cargo de la devoción religiosa. Las mujeres quedaron confinadas al hogar y tuteladas con la categoría de minoridad, motivo por el cual no podían trabajar, tener dinero ni estudiar.

El régimen planificó una política de postguerra que prolongaba y afianzaba la figura del rojo como el enemigo indiscutido. La manipulación del discurso ocupó un rol fundamental al respecto y, para revestirlo de una envergadura indiscutible, se recurrió a un discurso científico-biológico que lo sustentara. De este modo, Antonio Vallejo-Nágera, psiquiatra y militar, se encargaría no solo de considerar una categoría de raza para incluir a los franquistas sino también de pergeñar la existencia de un gen rojo. En tal sentido, el marxismo fue concebido como una enfermedad mental, lo que lo inscribía en el campo disciplinar del facultativo y le abría una vía libre para la experimentación. No es de extrañar ello, si se tiene en cuenta un viaje que realizó a Alemania para estudiar las concepciones nazis acerca de la eugenesia, entre muchos otros temas médicos de su interés. Por lo tanto, la tarea de separar a los hijos de sus padres para "desmarxitizarlos" (González Duro, 2012, 23) devino una práctica común en todos los ámbitos.

Los vencidos fueron perseguidos y encerrados en cárceles que al poco tiempo se vieron sobrepobladas. Los fusilamientos se convirtieron en moneda corriente. La situación de las mujeres no fue una excepción. Tal como hemos señalado en otro trabajo: "El abandono del hogar para vestir uniforme de miliciana y portar armas, saber manejar, haber donado sangre para milicianos, haber servido como enfermeras durante la guerra o haber ayudado en comedores infantiles, todo era motivo de condena”. (Gruber, 2020, 83). No perdamos de vista además, que:

El personal femenino de la falange cubría la seguridad de los centros penitenciarios. El trabajo en los talleres desempeñaba una función correctiva. Las órdenes de religiosas que operaban conjuntamente con el personal civil, se encargaban de la religión y la moral. Castigos, escarnios y "sacas"3 eran moneda corriente. (Gruber, 2020, 105) 
El hacinamiento, las enfermedades y los malos tratos hicieron mella en las reclusas. Al respecto, Santiago Castellà señala:

La represión fue especialmente dura y cruel contra las mujeres republicanas, militantes en causas sociales y de progreso, y también, en muchos casos, sobre las madres, esposas e hijas de los luchadores republicanos. Atacar la condición de la mujer era la respuesta espontánea desde concepciones morales basadas en la superioridad del hombre y en el fanfarroneo de la virilidad, que encajaba adecuadamente con aquellas concepciones religiosas que preconizaban el sometimiento y sumisión de la mujer. $(2018,10)$

En algunos penales se les permitía ingresar a las madres con sus pequeños, hasta los tres años, momento en el que se los separaba y se los derivaba a instituciones de menores. El estar embarazadas no las libraba de los juicios sumarísimos, solo que la ejecución se llevaba a cabo cuarenta y ocho horas después de dar a luz.

La situación de la mujer no mejoraría en la postguerra. El Patronato de Protección de la Mujer, creado en 1952 y presidido por Carmen Polo de Franco:

[...] tenía como objetivo legalmente declarado velar por todas aquellas mujeres que, caídas, desean recuperar su $<<$ dignidad $>>$, y cuyas instituciones represivas perduraron hasta $1985 \ldots$ ¡H Hasta 1985 ! Miles de mujeres, hasta la edad de veinticinco años, fueron encerradas sin juicio, condenadas a trabajos forzados de lavandería, cocina, limpieza y costura, principalmente, y cuyos hijos -de ingresar embarazadas- eran en muchos casos robados bajo inducción, coacción, amenaza o engaño. (Castellà, 2018, 12)

Con respecto a los niños, algunos de ellos llegaban a los hogares de Auxilio Social, colegios e institutos religiosos, mientras que otros eran entregados a familias del régimen. A partir de la sanción de leyes que posibilitaron el cambio de apellido de los menores, éstos fueron inscriptos como hijos de familias del régimen. Tal como señalamos en un trabajo anterior (Gruber, 2020), más de 30.000 niños han sido robados y se han perdido en la noche de los tiempos.

Los cincuentas y sesentas abrirían la puerta para que médicos, religiosos y militares continuasen privando a hijos y padres de la posibilidad de permanecer unidos, creyéndose con el derecho de decidir el destino de los pequeños. Tal como se puede ver, ya no son las razones políticas las que motivan dichas circunstancias, sino que aquellos se arrogaron el derecho de sostener lo que creían debía ser la moral que la sociedad respetase, claro está, a cualquier costo.

$\mathrm{Al}$ respecto, creemos esclarecedora una pregunta formulada por Neus Roig:

¿Cómo es posible que si se consultan los programas informáticos que dan acceso a las estadísticas españolas, aparezcan madres que presuntamente $<<$ pa- 
rieron >> en España como primerizas con más de cincuenta años, en las décadas de los sesenta, setenta y ochenta del siglo XX y no se investigue de oficio? $(2018,27)$

Con el tiempo, el tráfico de bebés se convertiría además en un negocio lucrativo en el cual participaron diversas esferas de la sociedad. Estas prácticas continuaron protegidas por un velo de impunidad ya que ni las leyes de Amnistía, ni la de Punto Final sirvieron para frenarlo. El pueblo español debería aguardar aun a que las leyes de adopción (1987, 1996 y 2011) pusieran fin a la trata de recién nacidos. (Roig, 2018)

No han quedado documentos que registren las atrocidades cometidas, no obstante, el silencio al respecto se hace imposible de sostener para algunas de las víctimas. Lo cierto es que las redes sociales han jugado un papel fundamental: algunas de las víctimas de abusos han tenido la valentía de denunciar allí lo sucedido y pedir a otros que hubiesen corrido la misma suerte que se animasen a hacer lo mismo. De este modo, las redes de memoria comenzaron de a poco a movilizar esos recuerdos que se creían enterrados. Tal como cuenta la documentalista en la presentación del libro producto de la investigación realizada, el motor fundamental de todo fue el tesón por parte de una de las víctimas que insistió a lo largo de tres años acerca de la necesidad de compilar los testimonios. La labor de Armengou y Belis sería entonces la de interesar a TV3 de Televisio de Catalunya para que les diese carta blanca para llevar a cabo la pesquisa.

Las denuncias no paraban de llegar y, si bien debieron realizar una labor de selección acerca de qué incluir en el documental, todo lo demás fue compilado dentro de un volumen homónimo.

\section{Los internados del miedo en la pantalla}

Un anclaje verbal en letras beige amarillento sobre placa negra indica: "Durante todo el franquismo y hasta bien entrada la democracia, cientos de miles de niños y niñas pasaron años encerrados en internados". La tipografía tiene un aire nostálgico, ya que se ha optado por una que parece de máquina de escribir antigua, al tiempo que se escucha un coro vocal de niños cantando a capella. Por fundido encadenado aparece ante los ojos del espectador la imagen de un edificio antiguo, de un piso de altura, con arcadas y columnas, el pasto crecido por el abandono y un grupo de mujeres y hombres, adultos mayores, que avanzan -algunos de ellos con dificultad, ayudados por otra persona o asistidos por un bastón o andador- ingresando a una sala con muebles y objetos cubiertos con sábanas, al tiempo que una voz femenina en off afirma: Era un campo de concentración, mal llamado colegio. Los hombres quitan una sábana y descubren un gran crucifijo colgado en la pared el tiempo que una voz masculina explicita: Nosotros éramos la escoria de la sociedad, niños abandonados. Se vuelve a escuchar el coro y una placa explica: "Allí fueron víctimas de abusos físicos, psiquiátricos, sexuales, explotación laboral o prácticas médicas dudosas”. La tarea 
continua, con el rostro constreñido, siguen descubriendo bustos, camas, cunas, etc. La voz de una mujer sacude con su afirmación: Me quemaban el culo con velas... Por orinarme. Otra voz femenina interroga: ¿Qué éramos en el colegio? Esclavas. ¡Éramos esclavas! Otra mujer afirma: Lo que le hice a ese señor se llama felación, pero en esa época yo no tenía idea. Un Plano Cenital capta como descubren un banco de iglesia de la funda que lo protegía. Se pasa nuevamente a una placa cuyo anclaje indica: "Hoy destapan este pasado oculto y silenciado, que nunca ha sido juzgado ni reparado". Todo presenta suciedad y es fiel exponente de años de abandono. Descubren también bancos con enseres escolares, cuyos planos hacen pensar que se trata de objetos más recientes que acompañan un afiche con el nombre del film. Una voz afirma: Pensé en suicidarme. Que un niño de doce años piense en eso es muy duro. Un Plano Detalle muestra en una hoja blanca, apaisada, escrito con tinta negra, en letra manuscrita "Els internats de la por" (Los internados del miedo) subrayado en rojo y, junto a ello, el dibujo de un niño en blanco y negro, mientras sigue la música coral.

Por fundido pasamos al Plano General contrapicado de un edificio bajo, junto a una alta torre de varios pisos coronada por una cruz, el anclaje señala "Hogares Mundet - Barcelona". Un anclaje verbal indica: "Joan Sisa. Internado de los 4 a los 18 años" se puede ver al hombre, sentado al aire libre en el sitio en el que se refugiaba cada vez que huía, narra que se escapó tres veces al tiempo que afirma: $Y$ sobre todo, saber que no me mandaba nadie, ni me pegaba nadie, ni sufría como sufrí, los abusos sexuales. Un Plano Detalle muestra la ficha de identificación del Hogar donde figuran sus datos personales, familiares y una foto carnet en blanco y negro, mientras se escucha su relato en off ya que, cada una de sus evasiones terminó con la Guardia Civil que lo devolvía al colegio y, como señala: Me caían unos castigos ejemplares. La fotografía funde entonces con un dibujo del mismo tamaño, en blanco y negro, que representa la imagen de un niño en una foto carnet. El fondo sepiado parece antiguo. Sobre él comienzan a aparecer imágenes en relación a lo que narra. La imagen del cura Isidro Fábregas que abochornaba y castigaba a los niños delante de sus compañeros -imágenes de dibujos que muestran Primeros Planos de niños- al tiempo que se escucha la voz que sigue narrando cómo le gritaba, lo subía a una silla, lo tomaba de las orejas e iba subiendo y subiendo tirando de estas hasta que al llegar a su altura lo soltaba y abofeteaba, con el dolor que ello implicaba.

Joan señala que conocía el castigo pero lo que más temía era esa humillación a la que era sometido. La cámara abre a un Plano General del hombre sentado y por corte directo, se pasa a las imágenes documentales grabadas de los Hogares Mundet. Sin lugar a dudas se trata de un fragmento de corte propagandístico que contrasta a todas luces con el testimonio anterior. Se pueden ver imágenes de archivo que muestran un certamen atlético con multitud de niños con ropas deportivas que, al aire libre, hacen un esquema gimnástico que culmina con escribir Mundet con sus cuerpos ante el público presente, entre ellos el presidente de dicha institución. Una voz en off masculina, indica que estos eventos tenían una finalidad propagandística: "Para dar una imagen moderna de la beneficencia".

El documental va cubriendo diversos centros: los Hogares Mundet, la Casa de la Maternidad de Barcelona, el Preventorio Antituberculoso de Playa de la Savinosa en Tarragona, el Preventorio Antituberculoso de Guadarrama, el Colegio San Fernando y la Casa de 
la Caridad, estos últimos en Madrid, el Instituto Psiquiátrico de Mujeres. Los anclajes verbales ubican al espectador espacialmente, al tiempo que una locución masculina suele comunicar datos que contextualizarán los testimonios que a continuación se presentan. Una cámara en plano cercano, generalmente Plano Medio registra a los testigos: hombres y mujeres que fueron víctimas de situaciones de abuso, explotación y violencia en los centros mencionados. La cámara está ubicada en posición frontal y solo se recurre a planos más cercano (Primerísimo Primer Plano) cuando se desea remarcar alguna situación emotiva producto del llanto o bien algún Plano Detalle de manos o gestos. Como fondo, junto a los testigos suele aparecer algún mueble cubierto por una sábana blanca, lo que funciona como recordatorio de aquello que se halla oculto a la vista. La escena suele presentar una clave de iluminación baja, se utiliza una luz azul como fondo tras los entrevistados y por momentos sobre las mencionadas sábanas.

Un anclaje verbal indica: "Carlos Carceller - Internado de los 7 a los 17 años" y, a continuación, se lo escucha afirmar: Una de las cosas que más me llamó la atención es que yo dejé de llamarme Carlos o Carceller... De entrada yo era 194.

Ello se halla reafirmado por Juan Antonio Miguel, de quien el espectador se entera a través del anclaje verbal, que estuvo recluido de los o a los 18 años: Eras un número.

Basta recordar que una de las estrategias llevadas adelante en los campos de concentración durante el nazismo era asignar a los prisioneros un número, como forma de despojarlos de su identidad. Cosificados de este modo, perdían todo vestigio humano que los identificase o inscribiese como individuos pertenecientes a una sociedad. Tal como se puede ver, los métodos mencionados no se alejan de dichas prácticas.

Ante la falta de imágenes que den cuenta de castigos o situaciones rememoradas por las víctimas, el documental recurre al dibujo animado. De este modo, siluetas dibujadas en marcador negro sobre un fondo sepiado, presentan a través de la animación aquellas imágenes de las que se carece, pero que son recuperadas a través de los relatos orales de las víctimas. Se puede observar que este recurso cubre adecuadamente dicha carencia y carga semánticamente los testimonios, permitiendo además enfatizar a partir de mínimos recursos cromáticos o iconográficos aspectos que de otro modo podrían haber pasado inadvertidos al espectador. Será Joan Sisa, uno de los abusados, quien narre su terrible experiencia. Castigado, era obligado por la noche, en pijama, a colocarse en el pasillo de cara a la pared. El dibujo esquemático de un pequeño de espaldas en medio de un gran pasillo resulta contundente. A continuación, aparece la imagen de un cura con sotana, una línea de color rojo funciona como nexo vinculante entre ambas figuras mientras la voz en off del hombre relata los abusos del capellán hacia el pequeño en situación de indefensión. El denunciante señala: $Y$ te tocaban como si manifestasen cariño, $y$, en caso de que pudieses ¿A quién lo podías denunciar? Las palabras quedan flotando y cobran más contundencia aun con lo que se afirma a continuación: como el perro que sigue a quien le pega, lo mismo hacían ellos, unos niños, ya que no tenían a quién seguir.

Un dato no menor lo constituye el testimonio de Carlos, que da cuenta de la creación de una suerte de grupo de autodefensa: habían sido testigos del abuso de dos niños, motivo por el cual se comenzaron a trasladar al baño en grupos para evitar que ello se repitiese. 
El espectador se podría preguntar pues, cuál era el motivo por el cual les sucedieron estas cosas y Carlos, parece echar luz al respecto: Nosotros éramos la morralla de la sociedad: $\mathrm{hi}$ jos del pecado, padres en prisión, niños abandonados... Era un sistema fascista el que había en este país. Era una impunidad total, y nosotros no éramos nada.

El siguiente tramo traslada la atención a la Casa de la Maternidad en Barcelona, tal como señala un nuevo anclaje verbal.

Este será el caso de la intervención de la periodista Carmen Alcalde y la abogada Magdalena Eurenik, quienes visitan el archivo de la Casa Maternidad. Allí son recibidas por Juan Antonio, el archivista, que fue uno de los niños que se educaron allí. Los planos generales permiten observar la moderna biblioteca y el archivo. Un Plano Detalle de un artículo de la Revista Destino del año 1968, titula: "Los hijos del pecado". A la sazón, la denuncia de la periodista pondría en el ojo de la tormenta la primera denuncia que daba cuenta de lo acaecido con los menores. Un Plano Detalle focaliza sobre algunos fragmentos que aparecen resaltados en negritas para llamar la atención del espectador: "Los niños no tienen prácticamente comunicación humana con personas mayores, casi no les hablan, sólo órdenes precisas. No aprenden a jugar, no saben jugar". A partir de allí comienza el testimonio de Carmen, quien señala algo que la impresionó en el momento en el que había visitado el sitio y denunciado lo que vio en el artículo: el manoseo por parte de los niños. La necesidad de contacto físico de los niños se hace patente en su testimonio. Ella y la letrada sostienen que: Eran como cárceles, destacando además la ex periodista: la agresividad y odio que destilaban las monjas. En tal sentido, Eurenik señala que, pese a las leyes de Indulto y Amnistía los menores continuaron en los patronatos.

Un nuevo segmento traslada la atención a Playa de la Savinosa en Tarragona, indica el anclaje verbal. Se observa en Plano General un viejo edificio derruido, se trata del Preventorio Antituberculoso. Javier Moreno y Manuel Martínez, explican cómo fueron los tres meses que pasaron internados allí. Pese a ser niños tenían prohibido realizar acciones cotidianas como correr o levantarse a voluntad de sus camas, motivo por el cual solían ser golpeados en las plantas de los pies. Los hombres recuerdan con los años que eran llevados a la playa y obligados a permanecer en cuclillas con la cabeza apoyada sobre las rodillas por horas o bien, que en instancias de castigo, debían colocar sus rodillas (y con ellas, todo el peso del cuerpo) sobre el dorso de las manos, tornándose el dolor intolerable. Cabe señalar que recuerdan las vejaciones y humillaciones como un "gran trauma eterno", palabras que son pronunciadas en medio del llanto.

El siguiente anclaje verbal indica: Preventorio Antituberculoso de Guadarrama.

Una filmación de corte propagandístico de 1966, recoge las imágenes de la visita de la niña número 1.000.000 en recibir la vacuna antituberculosa. Se puede ver en este fragmento la algarabía de niños y personal al recibirla casi como una figura heroica.

Se explica que los niños que eran llevados a los preventorios, no eran niños portadores de la enfermedad, sino que habían tenido contacto estrecho con algún familiar contagiado. Los testimonios de Julia García y Dolores Zamorano contrastarán dolorosamente con el fragmento del documental anteriormente señalado. 
A Julia le dijeron que iba a estar internada 3 meses, pero tal como indica el anclaje que acompaña su nombre, estuvo recluida allí de los 8 a los 13 años. La mujer rememora que al llegar lo primero que hicieron fue cortarle el cabello -que le llegaba a la cintura- porque dijeron que tenía piojos.

Dolores recuerda entonces qué les dijeron: Estas piojosas, asquerosas, muertas de hambre. ¡En fin! Insultos de todo tipo: ;Vamos guarras! ¡A las duchas! Al tiempo que agrega: De agua fría... ;En Guadarrama!

El alegato de otra internada, Marian Andrade, se encamina en el mismo sentido al narrar que suponía que la llevaban de vacaciones y que, al informar a las cuidadoras que se debió de haber producido algún error, se burlaron de ella y la abofetearon.

La voz en off de una de las mujeres señala: Al día siguiente nos levantan con un pito y nos sacan al patio nevado, descalzas. $Y$ nos dicen que eso es para que sepamos que tenemos que seguir las normas... Y que por supuesto, a los familiares lo que pasa en el centro, ni pío.

Se vuelven a retomar imágenes en blanco y negro de documentales de corte propagandístico que muestran a las niñas perfectamente vestidas, sentadas ordenadamente en el comedor infantil, comiendo lo que la locución indica que se trata de apetitosas comidas para las menores.

En Plano Medio, Itziar del Salto, quien estuvo un año internada, tal como señala el anclaje, contrasta: En las lentejas había gusanos, que era lo más normal del mundo o en las judías o en lo que hubiese. ¡Además es que tú los veías moverse! ¡Te costaba! ¡Te costaba tragarte eso! Por montaje se escucha el testimonio y se ven los fragmentos del documental anterior. Dolores Zamorano refuerza el testimonio de su compañera explicando que vomitó y la obligaron a comer lo que había vomitado. En este punto queremos señalar que la voz en off de la entrevistadora repregunta: ¿Lo que habias vomitado? Y Dolores responde en llanto: Sí, sí, lo volví a comer.

Julia García narra también que solo les daban medio vaso de agua al día, por la tarde y en vaso de aluminio, por lo que se deshidrataban, pero que ella con el paso del tiempo comía la pasta dental para no sentirlo. Asimismo, narra cómo de un golpe el cura la dejó sorda de un oído. La niña preparaba su comunión y le preguntó al religioso qué era la hostia. Éste le pegó un fuerte cachetazo que la hizo caer y sangrar, al tiempo que burlándose le dijo: Lo que te he dado es una hostia.

Mikae Ortiz describe cómo la castigaban por orinarse en la cama: quemándola con una vela o frotándole ortigas en sus partes íntimas.

Es este momento se muestran imágenes de documentales de la época y la voz en off masculina señala: "Muchos de ellos conservan un buen recuerdo de su estancia en aquellos centros, más en sintonía con la cara amable y caritativa que se vendía. Ciertamente en muchos internados la disciplina nunca traspasó la línea roja de la crueldad." Sin embargo, señala que junto a ellos, surgieron también: "cantidad de testimonios de abusos con una frecuencia estremecedora." Y agrega que: "no parece haber directrices para cometer abusos, pero tampoco había consecuencias para quienes los practicaban.” 
Un nuevo anclaje acompaña la imagen de Dolores: "Dolores era una niña sana pero en Guadarrama enfermó".

El testimonio de la mujer es registrado en planos cortos, su ubicación frontal y la cercanía del registro permiten captar su sufrimiento. Relata cómo el cura que la preparó para tomar su Primera Comunión abusó de ella y a continuación las amenazas de las que fue víctima: Tú estas cositas, no se las puedes decir a nadie. Tú verás: si Dios se enfada contigo, tú no volverás a ver a tus papás. Tú nunca volverás a ver a tus papás. Tus papás además, se pueden morir... Un Plano Detalle de un crucifijo y el Primerísimo Primer Plano de la mujer acompañan su relato en el que describe cómo la obligó a practicarle sexo oral y cómo, con el paso de los años, no ha podido quitarse la idea de que quizás fue su culpa y podría haber hecho algo para evitarlo.

El siguiente testimonio no es menos desgarrador. El anclaje verbal indica: "Ana se liberó cuando aceptó que era transexual. Dejó atrás a Antonio, un niño que pasó por diversos centros de Auxilio Social". Luego señala: "Ana Huelves internada de los 5 a los 16 años." En este caso la denuncia recae sobre el cura castrense Bielarrasa a quien: A veces tuve que hacer felaciones. No deja de llamar la atención en su testimonio cómo fue manipulado inicialmente por el religioso, ya que afirma: $Y$ yo convencidísimo que me estaba enseñando. Sin embargo, Ana relata a continuación la terrible violación de la que fue protagonista, motivo por el cual fue internada más de un mes en la enfermería del Centro: Pensé en suicidarme... que un niño de 12 años piense en suicidarse es terrible... Me marcó la vida. El siguiente segmento acompaña a Joan y Ana al Arzobispado Eclesiástico de Barcelona donde intentan radicar una denuncia por los abusos sufridos a manos de curas de la iglesia católica. Santiago Bueno, Vicario del Tribunal Eclesiástico de Barcelona los recibe. La voz en off del locutor señala que: "el modo en que el Papa Francisco enfrentó los casos de pederastia en el seno de la iglesia cristiana los ha animado. Además, y en contra de lo que pueda parecer, la justicia eclesiástica es más dura que la civil en casos de abuso por que el delito no prescribe hasta veinte años después de la mayoría de edad". Empero, los denunciados han muerto y con ellos cualquier posibilidad para los damnificados. Ana y Joan han encontrado sin embargo quien los escuche y contenga. La entrevista se halla captada en la Vicaría №1 y está tomada con Planos Medios. Finalizada la misma, los documentalistas entrevistan a Bueno quien explica cómo son en la actualidad los pasos que se siguen: se denuncia ante la autoridad civil, al juzgado de guardia y a la Santa Sede, a la Congregación de la Doctrina de la Fe y señala que es la Santa Sede la que vigila que los obispados procedan como deben hacerlo. El Vicario señala: Puede haber misericordia y perdón pero se hace justicia. Puede haber misericordia con el pecador pero tiene que haber justicia.

En el siguiente tramo se cubre el Colegio San Fernando, ubicado en Madrid, indica el anclaje verbal. La voz en off de Miguel Ángel Pardo que estuvo encerrado de los 0 a los 20 años, narra algunos de sus padecimientos. Se puede señalar que un anclaje indica que, sin embargo, permaneció trabajando en San Fernando, que nunca salió hasta los 39 años, que nunca logró integrase a la vida en el exterior y que, actualmente, sigue trabajando allí. De sus labios oímos: Era como una cárcel para niños y había más tiempo de tristeza que de alegría. La locución señala que San Fernando representaba la concepción franquista de beneficencia y que "los Ministerios de Gobernación y Justicia se repartían situaciones tan diversas como 
niños huérfanos pobres, chicas que podían caer en la prostitución o menores delincuentes". Por otra parte señala que si bien Auxilio Social y otras instituciones se crearon para canalizar este tipo de situaciones no menos cierto es que: "La mayoría de las veces se delega en colegios religiosos que cobrarán por cada niño que atiendan. La colaboración de la iglesia católica permitía asegurar caridad a cambio de adoctrinamiento político y religioso." Los Planos Detalles de fotografías de niños y en especial de uno besando la mano de un cura acompañan el relato en off: San Fernando era un campo de concentración mal llamado colegio, señala Cándido, quien denuncia: Hubo uno que recuerdo, Porfidio Castro. Bueno, eso, era sádico por naturaleza. Era el mal personificado en una persona con sotana. Cándido narra cómo el cura tomaba tres o cuatro cinturones, se los enroscaba en la mano y los blandía como látigos sobre los niños. En este momento, el dibujo animado ilustra sus dichos: el Plano Detalle de la mano con los cinturones, el Plano Medio del cura cuyo cuello no es blanco sino rojo y, asimismo, su nariz es un crucifijo rojo. El hombre relata un hecho de violencia física a través de ese cruel castigo que cayó sobre un pequeño: Para mí aquel niño estaba muerto porque estaba allí, inerte. El dibujo muestra entonces un niño en posición fetal y poco a poco se va extendiendo sobre él una mancha roja, transparente (ya que permite ver debajo el dibujo mencionado), hasta cubrirlo totalmente. El relato de Cándido va en consonancia con otros testimonios que aparecen a lo largo del documental, los entrevistados afirman que los niños desaparecían y nadie volvía a hablar de ellos.

Los relatos continúan, las víctimas desean ser escuchadas, desean una reparación. Han sufrido lo indecible: Me robaron la infancia. Me robaron la adolescencia. Abusos, torturas, vejaciones. La larga lista continúa. El locutor señala con voz en off: "Los niños sin padres o de familias pobres o represaliadas eran carne de cañón para unos maltratos físicos, psíquicos y sexuales que se quedaban puertas adentro." Ello queda claro ya que luego se informa que las cartas de los internos eran censuradas y los días de encuentros con los familiares eran una gran puesta en escena donde se los vestía con las mejores ropas y se les daba comida para la ocasión.

El anclaje señala: “José Florencio Sobrino. Internado de los 5 a 17 años.” Un hombre canoso, tomado en Primer Plano mira a la cámara y relata que Fernando Bello, director de San Fernando le dijo: Tu estancia aquí se ha terminado. Te ha adoptado un hombre, Te vas a ir con él a León. Narra a continuación su negativa, ya que tenía padres y él vivía en Ávila y cómo lo hicieron salir del despacho y él oyó la conversación que se producía en el interior: - Bueno, ¿cuánto le tengo que dar por el niño? / -Cien mil pesetas. José Florencio afirma: ;Yo fui vendido! ;Eso fue una venta directa!

En la siguiente escena se lo ve con unos papeles. Un Plano Detalle muestra lo que ve: su ficha escolar que afirma que egresó a los diecisiete años. Sobrino lo niega ya que, tal como explica, fue vendido a un carabinero y llevado al campo, donde sufrió la soledad, castigos físicos y privaciones. Y que más allá de las cicatrices físicas que le han quedado producto de las golpizas: Las secuelas del alma, son las peores.

La voz en off del locutor señala cómo consiguieron el expediente y: "cómo taparon la 'venta' de ese niño de doce años para trabajar en el campo de León." Asimismo que, como en este caso, pudieron detectar una docena más de casos similares de ventas de menores para labores rurales. 
A fines de los 60 el Colegio San Fernando sería denunciado por partirle la cara a un niño. Los periodistas fueron corridos de la escuela a piedrazos, por los niños, quienes a la sazón fueron manipulados por el director del centro. Sin embargo, la denuncia periodística y la intervención del Concilio cambiaron las condiciones de los pequeños. La vida mejoró, el colegio se abrió al exterior y la educación se tornó de excelencia.

No todos los centros corrieron la misma suerte, otros testimonios dan cuenta de ello.

A continuación, se narrará la historia de Isabel Perales internada de los 14 a los 20 años, indica el anclaje. La madrastra de la joven fue apresada luego de la Guerra Civil. Isabel tenía profundos deseos de aprender a leer y escribir por lo que, ante un decreto de Franco que supuestamente garantizaba educación para los hijos de los presos políticos, ingresó en un centro religioso. A diario sufría amenazas de las monjas: Hijita, hijita, hijita. De su comportamiento depende la vida de su madrastra, o bien: Hay que terminar con las ramas para que no lleguen a ser troncos. El relato continúa: nunca aprendió a leer ni escribir, apenas se podía mantener en pie por el hambre y debía estar lavando de la mañana a la noche. Sus manos se cubrieron de llagas y pus, pero ello no la exceptuaba de continuar con su tarea, ya que cada vez que se quejaba recibía como respuesta, por parte de las monjas: Ofrézcaselas a San José por los pecadores. Más sufrió nuestro Señor Jesucristo y nunca se quejó. Un Plano Detalle muestra sus manos temblorosas al tiempo que señala: ¿Qué éramos en el colegio? ¡Esclavas! ¡Éramos esclavas!

¿Qué era lo que había que lavar? ¿Por qué la mano esclava? El siguiente tramo del documental despejará estos interrogantes.

Un anclaje verbal señala a "Encarnació Clotet internada de los 11 a los 21 años." La mujer narra cómo estuvo encerrada trabajando para las monjas. Fue llevada con engaños ya que le habían prometido que podría estudiar. Sin embargo, la realidad es que debió coser a máquina durante años, al tiempo que afirma: A mí no me pagaron nunca nada, se lo quedarían ellas, supongo, porque allí todo el mundo trabajaba.

El testimonio de la mujer se yuxtapone por montaje con imágenes de documental en blanco y negro que muestra la labor en los talleres dirigidos por religiosas y niñas y adolescentes trabajando.

Los siguientes testimonios denuncian el trabajo esclavo de costura. La voz en off de Encarnació señala: Primero para el ejército, después para grandes almacenes. Yo no sé si era para Jorba Preciados o era El Corte Ingles. No sé para qué sitios era pero el tipo de trabajo era siempre coser a máquina. Con máquinas industriales.

Un anclaje verbal nos presenta a Itziar del Salto. Un año internada. Un Plano Medio la ubica frente a la cámara. Una voz femenina le pregunta en off: Mucha gente nos habla de El Corte Inglés ¿Cómo sabías que era El Corte Inglés? Sin dudarlo por un segundo, Itziar afirma: Por las etiquetas. [...] Claro, por las etiquetas que se ponen detrás de los jerseys y todas esas cosas, de El Corte Ingles (al tiempo que señala con la mano detrás del cuello, es decir en el sitio que se colocan las etiquetas de las marcas).

La locución indica a continuación que la investigación reveló que los centros religiosos firmaron contratos con grandes almacenes, haciendo grandes pedidos y agrega: "La firma comercial tenía y en algunos casos tiene todavía la concesión para para hacer la ropa del 
ejército, de la seguridad social, etc. Con los encargos en centros de beneficencia se obtenían mejores precios que si se hubiesen pedido en talles profesionales." A continuación se destaca que el trabajo se abonaba pero que dependiendo del centro ese dinero podía o no llegar a las trabajadoras.

Seguidamente se cubre el caso de "Consuelo García del Cid. Internada de los 15 a los 17 años", señala el anclaje. La mujer indica que solo cobró en el Buen Pastor. Relata que estaba en el taller de muñequería donde se confeccionaban muñecos para las pastelerías. Éstos se rellenaban con caramelos y que, en muchas ocasiones, junto a los caramelos colocaban pedidos de auxilio: Por favor, me llamo Consuelo. ¡Estoy presa! ¡Soy inocente! No he hecho nada, Adoratrices - Padre Damián 52 ¡Sáquenme de aquí!

García del Cid narra cómo fue encerrada. A la muerte de Franco, España comenzaba a respirar aires nuevos. Sin embargo, la militancia política era aun peligrosa. Consuelo era una adolescente rebelde que se saltaba las clases, participaba en manifestaciones y repartía panfletos -de haber sido sorprendida repartiéndolos la hubiesen sentenciado a cinco años de prisión-. Una mañana, muy temprano, fue despertada por su madre y el médico de la familia para "ponerle una vacuna" (sic). Lo que recuerda a continuación es haberse despertado en una habitación enrejada, cerrada con llave y que, al asomarse por la ventana solo veía vehículos con placas de Madrid, mientras que ella era de Barcelona. ¡Me habían metido en el Reformatorio de Las Adoratrices!

La voz en off del locutor señala que: "Consuelo ha investigado sobre esta especie de cárceles invisibles para niños y jóvenes que no habían cometido ningún delito.” En este tramo se destaca la creación del Patronato de la Mujer: "Esta institución, creada en 1941 se encargaba de la 'mujer caída o en riesgo de caer' es decir, vinculada a la prostitución." Más datos son suministrados a continuación: el Patronato patrullaba deteniendo a mujeres, en muchos casos embarazadas producto de violaciones: "de padres o hermanos. Paradójicamente, no se encierra al agresor, sino a la víctima que puede quedar recluida hasta los 25 años. La democracia española llegó tarde a esos centros que no se cerraron hasta los años ' 80 ”. Los Planos Generales captan a García del Cid en plena tarea de investigación en una Biblioteca, es ella quien aporta más datos: Una verdadera Gestapo española cuyas celadoras se dedicaban a cazar menores en actitud sospechosa. Pero ¿cuál era esa actitud sospechosa? Pues llevar una minifalda, darte morreo con tu novio en la última fila del cine o fumar $y$ estar en la calle en horario colegial.

Respecto del tráfico de niños, Consuelo destaca las pruebas halladas en su exhaustiva pesquisa: Llego a conseguir incluso una carta de petición de niños al centro de Peña Grande, ¡como si fuera $1 \mathrm{~kg}$ de naranjas! Un Plano Detalle de la misiva acompaña sus dichos, el pedido señala que se hace con "el propósito de prohijar".

Nuevamente se vuelve a entrevistar a Itziar, quien señala: Es que desaparecían los niños... Fíjate que en el año 70 cuando yo di a luz... de 300.000 a 500.000 pesetas se pagaba por un niño. García del Cid aporta un nuevo dato: aquellas jóvenes que no podían soportar lo que les sucedía eran trasladas a un manicomio. Ello sirve de enlace para abrir el siguiente tramo, cuyo anclaje señala: "Casa de la Caridad - Madrid." Aquí se escucha el testimonio de Júlia Ferrer - Internada de los 2 a los 24 años y de Quimeta Mayals - Internada de los 0 a los 31 años. 
Ambas mujeres dan cuenta de haber recibido electrochocks. El análisis de la voz en off del locutor da cuenta -en función de la historia clínica de Júlia- que se trataba de una niña normal, rebelde: "la historia de Júlia revela más bien el comportamiento propio de una niña internada en un centro de beneficencia que el de una enferma mental." Fue la amistad de Quimeta la que la ayudó a sobrevivir en ese infierno.

\section{Cuando la realidad supera la ficción}

El 28 de diciembre de 1895, en el Grand Café del Boulevard de los Capuchinos se producía la primera función pública y paga de la historia del cine. París saludaba el nacimiento del cinematógrafo. Los films exhibidos fueron los primeros documentos de la realidad que rodeaba a los cineastas: el desayuno del bebé, la salida de los obreros de la fábrica Lumière y la llegada del tren a la estación. Todos temas cotidianos, algunos de ellos a la sazón habían sido captados entre otros, por la paleta de Claude Monet, cuando una de las preocupaciones de los artistas plásticos era captar la incidencia de la luz sobre los objetos. No en vano, Lumière encaminaría sus pasos y su cámara en tal sentido, siendo considerado por algunos autores como el último pintor impresionista. (Barnow, 1998) Con el tiempo, el documental fue legitimándose como documento y se discutió, largamente, su estatuto de verdad. ¿Ficción? ¿Realidad? ¿Documento fotográfico?

El estudioso de cine Carl Plantiga señala que:

Considerar el film documental como un mero documento fotográfico ignora la "formación creativa" que constituye un elemento inevitable de todas las películas documentales, y esto ocurre en diversos registros, tales como la estructura retórica o narrativa, la edición, la dirección de fotografía, el diseño de sonido y, más polémicamente, las reconstrucciones y aún la manipulación de acontecimientos profilmicos. (2011: 1)

Asimismo, no debemos olvidar que al abordar las relaciones entre cine e historia, los estudios de Marc Ferro fueron un aporte fundamental en el siglo XX, al considerar al cine como fuente y agente de la historia. En tal sentido, y siguiendo el camino trazado por Ferro, Robert Rosenstone aporta algunos conceptos que creemos atinados recordar:

Lo que vemos en la pantalla sólo puede ser una aproximación de los que se dijo e hizo en el pasado; la pantalla sugiere lo que ocurrió, no lo describe. Esto significa que necesitamos aprender a juzgar los mecanismos mediante los cuales el cine resume la amplia información de referencia o recoge simbólicamente aspectos complejos que de otra forma no podrían ser vertidos en imágenes. (1997: 59) 
Trataremos pues, de interpretar algunos de los elementos que Armengou y Belis pusieron en juego a la hora del armado del documental.

Indudablemente, se trata de un film de tipo coral, tal como hemos podido apreciar en la secuencia de presentación. Las voces de hombres y mujeres mayores, a quienes se ha podido ver avanzar y descubrir simbólicamente los muebles y objetos, les permitirá también exponer esos recuerdos que ocultaron y acallaron durante tanto tiempo. La acción de desocultar refuerza desde el plano visual aquello que desplegará a lo largo del film mediante el uso de la palabra.

$\mathrm{Al}$ aproximarse al estudio del documental, el profesor y estudioso sobre cine, Bill Nichols señala:

El estilo implica directamente al documentalista como sujeto humano; lo que vemos, a diferencia de lo que vemos en una ficción, no ofrece el espacio conjetural de una metáfora. [...] En el documental tenemos constancia de cómo los realizadores ven, o miran, a sus congéneres directamente. El documental es el registro de esa mirada. La implicación es directa. El estilo atestigua no solo una $<<$ visión $>>$ o perspectiva sino también la cualidad ética de dicha perspectiva y la argumentación que hay detrás de ella. $(1997,119)$

En tal sentido, creemos que el film Los internados del miedo manifiesta indudablemente un respeto por las personas que brindan su testimonio que se evidencia a través de planos cercanos -ya sea Planos Medios o Primeros Planos- deteniéndose, además, en Planos Detalles de manos y gestos que sirven al espectador para escrutar en los alegatos, captar el dolor, la vergüenza y el sufrimiento. Mediante la cercanía de los planos y las tomas largas se crea un clima pausado, respetuoso, que sin prisas cubre y descubre quiebres en la voz, llantos, palabras y gestos portadores de un dolor inenarrable. El dolor de las víctimas.

Los entrevistadores no se hacen presentes en el espacio profílmico, sin embargo, en algunos momentos una voz en off femenina, pregunta algo que desea que los entrevistados aclaren. En muchos casos vemos que algunos de los indagados son amigos y esa amistad se traduce en el afecto que revela cómo se miran, qué impresiones guardan o cómo se ayudan y sostienen entre sí.

Creemos que el recurso del dibujo en blanco y negro, con una animación cuidada, el contraste del blanco y negro sobre el fondo sepiado y apenas unos pocos trazos de color rojo para resaltar la sangre, por ejemplo, cargan semánticamente las escenas. Ello se halla reforzado también desde el plano sonoro de risas y llantos que acompañan a las descripciones de las víctimas.

A lo largo del documental va quedando expuesta cómo la práctica de separar a los "rojos" de sus hijos, no solo se desarrolló a lo largo de la época de la Guerra Civil y la posguerra, sino que se extendió hasta entrada la década del ' 80 . A través de todos esos años, instituciones religiosas, civiles y sanitarias se arrogaron el derecho de decidir sobre la vida y la moral de los españoles. De este modo, ser comunista, esposa, novia o hijo de ellos; ser pobre y tener una familia numerosa; haber caído en "pecado", haber sido violada o ser hijo 
de una prostituta fueron las injustas excusas para separar familias enteras. Por otra parte nos enteramos también de que ser familiar de alguien que había contraído tuberculosis, hacía que la labor sanitaria de aislar a los pequeños se convirtiese en muchos casos en una separación forzada de una crueldad extrema.

Si bien no todos los empleados ni los religiosos de los centros para menores abusaron física ni mentalmente de los internos, llama poderosamente la atención la cantidad de denuncias que los documentalistas recabaron. Dado que dichos testimonios sobrepasaban la extensión del material audiovisual, decidieron recoger en un volumen homónimo todo aquello que no llegaron a cubrir, tal como hemos señalado.

Los alegatos resultan contundentes, el común denominador: la filiación política de los padres, la pobreza y la ignorancia, permitieron a todo un régimen poner en funcionamiento no solo la sistemática eliminación de un enemigo político, sino trasladar el sufrimiento a pequeños cuya única culpa fue haber nacido. De este modo, todo mecanismo fue válido para abusar, castigar, hostigar, vigilar, encerrar e invisibilizar a los menores. Recluidos porque sus padres estaban presos, separados de sus familias bajo excusas sanitarias o morales, muchos de ellos cargan con traumas que nunca llegarán a superar. El documental recoge testimonios que van desde castigos inhumanos a electroshocks, desde violaciones hasta trabajo esclavo de menores, desde venta de bebés a tráfico de personas. Nada parece despertar el interés de los gobiernos de turno. Bástenos señalar que ningún gobierno democrático les ha pedido disculpas por lo sucedido ni tampoco se los ha considerado como víctimas del franquismo.

Tal como afirma Elizabeth Jelin resulta imposible hallar una verdad, una memoria de un determinado período y, dependiendo de las circunstancias, en determinados momentos podremos hallar un "libreto único" (Jelin, 2002: 6) ya sea más hegemónico o más aceptado. Es decir, aquel que esgrimen los vencedores. Se entabla de este modo una lucha entre las verdades alternativas que subyacen en las sombras, en las "catacumbas" como las denomina la autora, que pujan por salir a la luz. En consonancia con esto señala con sagacidad que:

El espacio de memoria es entonces un espacio de lucha política, y no pocas veces esta lucha es concebida en términos de $<<$ lucha contra el olvido $>>$ : $r e$ cordar para no repetir. Las consignas pueden en este punto ser algo tramposas. $\mathrm{La}<<$ memoria contra el olvido $>>$ o $<<$ contra el silencio $>>$ esconde lo que en realidad es una oposición entre memorias rivales (cada una de ellas con sus propios olvidos). Es en verdad $<<$ memoria contra memoria $>>$. (Jelin, 2002: 6)

Creemos luego de ver el documental que la verdad que permaneció enterrada durante tantos años puja por salir a la luz. Busca espacios en los cuales hacerse presente, ante la vacancia de sitios de denuncia en su propia tierra, la Querella argentina propició una esperanza para algunas de las víctimas. Sin embargo, no podemos dejar de destacar que esos 
delitos que arrancaron hace más de cuatro décadas respondieron a una política avalada por el gobierno franquista, por la Iglesia, por parte de la sociedad española y por grandes empresas comerciales que en connivencia con el poder llevaron adelante una macabra y lucrativa actividad. Muchos de los responsables han muerto, otros gozan de buena salud y siguen sus vidas como si nada hubiese sucedido. Mientras tanto, las víctimas aguardan, pero algo es seguro: desean ser escuchadas y ya nadie podrá callarlas. ¡Nunca más!

\section{Notas:}

1. Montserrat Armengou i Martin (Barcelona, 1963), Licenciada en Ciencias de la Comunicación por la Universidad Autónoma de Barcelona. Su carrera comenzó en medios gráficos, pasando a trabajar en 1985 en el programa 30 Minuts para Televisió de CatalunyaTV3. Allí realizó junto a Ricard Belis Los niños perdidos del franquismo (2002), Las fosas del silencio (2003), Ravensbrück, el infierno de las mujeres (2005), Monarquía o república (2012), entre otros.

2. Ricard Belis i Garcia (Barcelona, 1964), periodista y escritor catalán realizador de numerosos documentales. Los documentales y libros realizados junto a Montserrat Armengou han sido galardonados por su aporte al periodismo de investigación.

3. Por el film Los niños perdidos del franquismo Montserrat Armengou y Ricard Belis fueron galardonados con el Premio Nacional de Periodismo de Cataluña.

4. Por las noches, camiones abarrotados de presos de las prisiones eran trasladados a zonas despobladas o a los muros de los cementerios donde se fusilaba a los detenidos.

\section{Bibliografía}

Armengou, M., Belis, R. (2016). Los internados del miedo. España: Titivillus.

Barnow, E. (1998). El documental. Historia y estilo. Barcelona: Gedisa.

Feld, C., Stites Mor, J. (2009). (Comp.). El pasado que miramos. Memoria e imagen ante la historia reciente. Buenos Aires: Paidós.

Gruber, M. (2020). Cómo denunciar cuando todos callan: los niños robados por el franquismo. Marzorati, Z., Pombo, M. (Comp.). Violencia física y simbólica. Algunas reflexiones sobre el audiovisual y sus discursos. Cuadernos del Centro de Estudios en Diseño y Comunicación [Ensayos], 108, Bs. As.: UP, pp. 101-120.

Gruber, M. (2021/2022). Reflexiones sobre la construcción de la imagen femenina. La voz dormida: de Dulce Chacón a Benito Zambrano. Marzorati, Z., Pombo, M. (Comp.). Cultura audiovisual, memoria y género. Una perspectiva en crecimiento. Cuadernos del Centro de Estudios en Diseño y Comunicación [Ensayos], 95, Bs. As.: UP, pp. 81-96. 
Jelin, E. (2002). Los trabajos de la memoria. Madrid: Siglo XXI.

Nichols, B. (1997). La representación de la realidad. Cuestiones y conceptos sobre el documental. Barcelona: Paidós.

Plantiga, C. (2009). Documental, traducción S. Pardo. En Revista Cine Documental, No 3, 2011. Recuperado el 20 de abril de 2021 de: http://revista.cinedocumental.com.ar/3/ traducciones.html

Ranalletti, M. (2017) (Comp.). La escritura filmica de la historia. Problemas, recursos, perspectivas. Buenos Aires: EDUNTREF.

Roig, N. (2018). No llores que vas a ser feliz. El tráfico de bebés en España: de la represión al negocio (1938-1996). Barcelona: Ático de los libros.

Rosenstone, R. (1997). El pasado en imágenes. El desafío del cine a nuestra idea de la historia. Barcelona: Ariel.

\title{
Filmografía
}

Los internados del miedo (Els internats de la por)

Año: 2015

Duración: 76 minutos

Dirección: Montse Armengou, Ricard Belis

Fotografía: David Bou

Género: Documental

\begin{abstract}
In 2002, journalists Montse Armengou and Ricard Belis made Los niños perdidos del franquismo (Els nens perduts du franquisme), a documentary for TV3-Televisio de Catalunya, in Spain. The filmed material partially summarized what they would turn into a homonymous book. But after finishing their research, the accusations ketp coming. As Belis points out, the lack of evindentiary documents was not an issue, since they were a lot of denouncements that had to be deal with. This way, filmmakers focussed on an unknown episode in the Spanish past.

Los internados del miedo could easily be the title of a horror film, but it isn't, since truth is stranger than fiction. Los internados del miedo (Els internats de la por, 2015) by Montse Armengou and Ricard Belis, gathers the testimonies of humiliations, deprivation and even medical experiments of the victims of the Francoist Boarding Schools. Psychiatric Hospitals, Preventorioums, Orphanages and Boarding schools left a despicable mark in Spanish history, in which torture, rape, child labour and children trafficking played a significant role. We intend to tackle this documentary material in order to help restore the voice and identity of the silenced victims. Was poverty one of the causes of their situation? What happened to the single mothers' children? And those whose parents were well known anti-Francoist? This and other questions will guide our search. We will try to establish the causes that put those minors in a situation of terrible vulnerability, turning them in a
\end{abstract}


easy target for such practices. We must not fotget that in fragrant connivance the State, the Church and some companies, were responsible of a macabre and systematic programme.

Key Words: Francoism - audiovisual representation - children - memory

Resumo: Os jornalistas Montse Armengou e Ricard Belis fizeram o documentário Os Meninos roubados pelo franquismo (Els nens perduts del franquisme, 2002) para a rede TV3 da televisão da Catalunha da Espanha. O material do filme resumia apenas parte do que se transformaria em um livro de mesmo nome. Depois que a pesquisa terminou, as reclamações continuaram chegando. As vítimas queriam alguém para ouvi-las. Como Belis aponta, não importava que não houvesse documentos probatórios, pois tinham muitas alegações e precisavam ser tratadas. Desse modo, os cineastas direcionaram seus passos para um episódio desconhecido do passado espanhol.

Os Internos do Medo poderia ser tranquilamente o título de um filme de terror, mas não é, pois a realidade supera a ficção. Os Internos do Medo (Els internats de la por, 2015) de Montse Armengou e Ricard Belis coleta os depoimentos das vitimas de humilhações, privações e até experiências médicas nos internatos para crianças da era de Franco. Hospitais psiquiátricos, os preventórios, as creches e os internatos escreveram as páginas mais desprezíveis da história espanhola, nas quais a tortura, o estupro, o trabalho infantil escravo e venda de menores, faziam parte.

Nós pretendemos abordar este material documental para ajudar a restaurar a voz e a identidade das vítimas silenciadas. A pobreza pode ter sido uma das causas da sua situação? O que aconteceu com os filhos das mães solteiras? E aqueles cujos pais foram reconhecidos como anti-Franco? Essas e outras perguntas guiarão a nossa pesquisa. Nós tentaremos estabelecer quais poderiam ser algumas das causas que colocaram essas crianças em uma situação de maior vulnerabilidade, tornando-as um alvo fácil de tais práticas. Não podemos esquecer de que o Estado, a Igreja e algumas empresas em flagrante conluio foram os executores de um programa macabro e sistemático.

Palavras chave: Franquismo - representação audiovisual - crianças - memória

[Las traducciones de los abstracts fueron supervisadas por el autor de cada artículo] 